\title{
PHYTOCHEMICALS, VITAMINS,MACRO AND MICRO ELEMENTS AND ANTIMICROBIAL ANALYSIS OF THE STEM BARK OF NAPOLEONA VOGELII(AKPAESU)
}

\author{
By
}

* Eze, Sunday Onyekwere andAmajohChinwe Victoria

Department of Chemistry, Abia State University, PMB 2000, Uturu, AbiaState , Nigeria

Email: Sundayoeze@yahoo.com

\section{ABSTRACT}

Sequel to the increasing application of plant materials in ethnomedicine and for nutritive purposes the phytochemicals, vitamins, macro and micro elements and antimicrobial analysis of the stem bark of Napoleonavogelii were undertaken using standard methods. The result shows that Napoleonavogeliicontains bioactive phytochemicals such as tannin $(0.45 \pm 0.25 \%)$, phytosterols $(12.53 \pm 0.25 \%)$, alkaloids $(4.42 \pm 0.23 \%)$, flavonoids $(9.27 \pm 0.18 \%)$, saponins $(4.27 \pm 0.25 \%)$, hydrogen cyanide $(0.37 \pm 0.20 \%)$. The vitamin analysis shows that the stem bark of Napoleonavogeliicontains vitamin $A$ $(1.20 \pm 0.03 \mathrm{Mg} / \mathrm{g})$, vitamin $\mathrm{E}(1.31 \pm 0.04 \mathrm{Mg} / \mathrm{g})$, vitamin C $(2.78 \pm 0.04 \mathrm{Mg} / \mathrm{g})$, vitamin $\mathrm{B} 1(7.20 \pm 0.05 \mathrm{Mg} / \mathrm{g})$, vitamin B2 $(0.90 \pm 0.31 \mathrm{Mg} / \mathrm{g})$, vitamin B9 $(4.09 \pm 0.05 \mathrm{Mg} / \mathrm{g})$, vitamin B3(1.27 $\pm 0.25 \mathrm{Mg} / \mathrm{g})$, vitamin B6 $(12.50 \pm 0.04 \mathrm{Mg} / \mathrm{g})$ and vitaminB12 $(8.25 \pm 0.04 \mathrm{Mg} / \mathrm{g})$ in varying amounts while vitaminB5 and vitaminB7 wereabsent. Sodium(1247mg $/ \mathrm{kg})$, Calcium $(2006 \mathrm{mg} / \mathrm{kg})$,Copper(1.23mg/kg),Phosphorous $(410.22 \mathrm{mg} / \mathrm{kg}), \quad \operatorname{Iron}(304.660 \mathrm{mg} / \mathrm{kg}), \quad$ Manganese $(56.99 \mathrm{mg} / \mathrm{kg}) \quad$ and Zinc $(2.69 \mathrm{mg} / \mathrm{kg})$ were the detectable mineral elements, Potassium $(4996 \mathrm{mg} / \mathrm{kg})$ had the highest value while Arsenic and Nickel were below detection limit $(0.001 \mathrm{mg} / \mathrm{kg})$. The result of the antimicrobial screening of the ethanol, butanol and chloroform extracts of the stem bark of Napoleonavogeliiagainst five pathogenic microbes, Escherichia coli, pseudomonas aeruginosa, streptococcus sp, Staphylococcus aureus, and Candida albicans shows that the butanol extract showed higher antimicrobial activities compared to the other extracts. Results from this study have shown that the stem bark of Napoleonavogeliicontains medicinal properties.

\section{Council for Innovative Research}

Peer Review Research Publishing System

\section{Journal: Journal of Advances in Chemistry}

Vol. 11, No. 9

www.cirjac.com

editorjaconline@gmail.com, editor@cirjac.com 


\section{INTRODUCTION}

Plants are composed of vast array of phytochemicals and vitamins that characterize their pharmacologic properties and nutritional values [1]. Phytochemicals are naturally synthesized in all parts of the plant and may contain active components[2].Phytochemicals have been recognized as the basis for traditional herbal medicine practiced in the past and currently in parts of the world [3]. Plants and phytochemical compounds are used in folk medicine for the treatment of different types of diseases [4]. A typical example is the Napoleonavogelli whose methanol leave extract of is used in the treatment of peptic ulcer diseases [5] and the bark is used for treatment of skin diseases by the local folks [6]. Napoleonavogelii is an evergreen and widely distributed plant with alternate leaves, usually crowded towards the apex of the branches. About 20 genera and 450 species have been identified in the tropical regions of Africa, Asia and Australia. Its region of distribution is mostly in African countries of Nigeria, Ghana, Guinea, Togo, Benin and Ivory-coast [7]. Napoleonavogelii, (Lecythidaceae) is known locally as akpuruke, mkpodu, or odure by the lbos of South-East Nigeria. Its common names are Akpako, Boribons, Burukwa. The plant is found mostly in rain forest, along the sea shores extending from Sierra Leone to Nigeria. It is an ornamental shrub or tree $2.5-5 \mathrm{~cm}$ tall. The plant grows best in full sun but tolerates light shade. It prefers warm and humid climate and requires medium water/regular moderate drought tolerance. Its fruits are sweet and edible and the fruits ripe in dry season[8].

\section{MATERIALS AND METHODS}

\section{Sample Collection}

Fresh sample of Napoleonavogelii stems were collected from Uturu, in Isuikwuato Local Government Area of Abia State. The plant was identified by Mr. IbeKaluNdukwe of Michael Okpara University of Agriculture, Umudike, Abia State.

\section{Micro-Organisms Collections}

Pure cultures of bacterial strains, Escherichia coli, pseudomonas aeruginosa, streptococcus sp, Staphylococcus aureus, and fungal strain of Candida albicans were obtained from vetenary diagnosing laboratory veterinary research institute out station, Umudike, Abia state.

\section{Preparation of Plant Materials}

Freshly collected Napoleonavogelii stem bark was washed and dried under the shade at normal room temperature for 14 days. Upon drying, the stem bark was blended to powder. The powdered sample was then stored in air tight containers and kept under normal room temperature until required.

\section{Determination of Minerals}

The method described by [9] was adopted. $1 \mathrm{~g}$ of the sample was weighed into a beaker and $100 \mathrm{ml}$ of digestion mixture(nitric acid: sulphuric acid: perchloric acid) in the ratio 2:2:1 was added and the mixture was hated on a hot plate in a fume hood at $105^{\circ} \mathrm{C}$ until the production of white fumes which indicates complete digestion. $10 \mathrm{ml}$ of the de-ionized water was added to the digestateand was allowed to cool down to room temperature and filtered using No 42 watman filter paper into $50 \mathrm{ml}$ volumetric flask. The digestate was made to mark with de-ionized water and analysis of heavy metals was performed using Atomic Absorption Spectrophotometer AAS-Biotech 896,UK.

\section{Determination of Phytochemicals}

The plant extracts were screened for the presence of some phytochemicals using standard methods as described by[10] and [11].

\section{Antibacterial Activity}

Agar well diffusion method as described by [9] was employed to assay for the antibacterial activity.

\section{Determination of Vitamins}

The method of analysis employed were those described by [12]; [13] and[14]. 


\section{RESULTS AND DISCUSSION}

\subsection{QUALITATIVE PHYTOCHEMICAL SCREENING}

The result of the qualitative phytochemical screening of the stem bark of Napoleonavogelii is shown in table 1.

TABLE 1: The Result of the Qualitative Phytochemical Screening of the Stem Bark of Napoleonavogelii

\begin{tabular}{|l|l|l|l|l|}
\hline PHYTOCHEMICALS & ETHANOL & BUTANOL & CHLOROFORM & WATER \\
\hline Tannin & + & - & & + \\
\hline Alkaloid & + & - & - & + \\
\hline Saponin & + & - & - & + \\
\hline Flavonoid & + & - & + & + \\
\hline Oxalate & - & - & - & - \\
\hline Steroid & - & - & + & - \\
\hline Phytosterol & - & - & + & - \\
\hline Carbohydrate & - & - & + & + \\
\hline Cardiac glycoside & + & + & - & + \\
\hline Phenol & - & - & + & + \\
\hline Hydrogen cyanide & + & - & + & - \\
\hline
\end{tabular}

\section{KEY : + Present - Absent}

The result for the qualitative phytochemical analysis is presented on Table 1. The result revealed the presence of different phytochemicals that slightly varied with the solvent used for the extraction [15]. The presence of alkaloids, saponins, and tannins in the stem bark extracts of Napoleonavogelii has medicinal implication. These phytochemicals are known to be biologically active. They possess some properties such as antibacterial properties (tannins and flavonoids) antiseptic properties (tannins), anti-inflammatory properties (flavonoids,saponins), analgestic properties(steroids) and anaesttheticproperties (alkaloids)[16]. The presence of tannins was found to play a role in the antifungal, antibacterial, astringent and antibiotic activities[16]. Phenolic acids and flavonoids have been the object of a great number of studies of their anti-oxidative activity which is mainly because of their capacity to act as free radical scavengers and/or metal chelators [17][18]. Both compounds have attracted considerable interest in the past few years due to their many potential health benefits. As polyphe- nols, phenolic acids and flavonoids are powerful antioxi- dants and have been reported to demonstrate antibacterial, antiviral, anticarcinogenic, anti-inflammatory and vasiodilatory actions[19][20]

The above result is similar to the findings of Christainet al., [6] who in his report of methanol and petroleum extracts of the stem bark of Napoleonavogelii stated the presence of tannins, alkaloids and saponin. Previous phytochemical studies indicated the presence of alkaloids, tannins and saponins on Napoleonavogelii stem bark [16]. Though few works have been done on the phytochemicsls of the stem bark, it was found out that the leaves of the plant contained tannin, alkaloid, saponin, flavonoid carbohydrate and cardiac glycoside.[21] and the fruit plant contained tannin, alkaloid, saponin, flavonoid carbohydrate and cardiac glycoside [7]

\section{QUANTITATIVE PHYTOCHEMICAL SCREENING}

The result of the quantitative phytochemical screening of the stem bark of Napoleonavogelii is shown in table 2

The phytochemical result indicates that the flavonoid content of Napoleonavogelii stem bark is $9.27 \%$. This value is relatively high compared to the value of 4.65 reported of Napoleonavogelii Hook fruit [22]. However, [23] reported that high amounts of flavonoid help protect blood vessels from rupture or leakage, enhance the power of vitamin C; protect cells from oxygen damage and prevent excessive inflammation.

TABLE 2: The Result of the Quantitative Phytochemical Screening of the Stem Bark of Napoleonavogelii

\begin{tabular}{|l|l|}
\hline PHYTOCHEMICALS & QUANTITY PRESENT (\%) \\
\hline Tannin & $0.45 \pm 0.25$ \\
\hline Phytosterol & $12.53 \pm 0.25$ \\
\hline Alkaloid & $4.27 \pm 0.23$ \\
\hline Flavonoid & $9.27 \pm 0.18$ \\
\hline Saponin & $4.27 \pm 0.25$ \\
\hline Hydrogen cyanide & $0.37 \pm 0.20$ \\
\hline
\end{tabular}


The value obtained for tannin in the stem bark of this plant was $(0.45 \%)$. This value is lower than that reported forNapoleonavogelii Hook fruit [22] and the stem bark of Napoleonavogelii in methanol(9.5\%) and in petroleum ether(1.8\%) [6]. High tannin content in thesample implies severe nutritional challenge to animals or humans due to its affinity for certain digestive enzymes. The saponin value is $4.27 \%$. This is quite high compared to the value of $0.75 \%$ reported for Napoleonavogelii Hook fruit [22] and lower than the value of (1.8\%) in petroleum ether reported by [6]. A high Saponin diet can inhibit dental and platelet aggregation in treatment of Hypercalciuria in human (excessive urinary calcium excretion, an antidote against acute lead poisoning [24]. Saponin also decreases blood lipids, lower cancer risks and blood glucose response as well as posses antioxidant activity. Toxicology studies of saponin using relevant experimental models have established that even at an upper concentration of 3.5\%, saponin was safe and failed to cause systemic side effect [25].The value obtained for hydrogen cyanide in NapoleonaVogelii stem bark is $0.37 \%$ and is lower than the $36 \mathrm{mg} / 100 \mathrm{~g}$ considered lethal dose for man [26]. The alkaloid content $(4.27 \%)$ is low compared tothat reported by [6].Caution should be taken in the consumption of plant materials with very high concentration of Alkaloid because they could inhibit certain mammalian enzymes activities such as those of cyclic adenosine monophosphate (AMP) [27]. European Food Safety Authority [28] stated that since cooking only lowers alkaloid content of foods by $40-50 \%$, highly sensitive individuals should avoid this category of food entirely.

\section{VITAMINS ANALYSIS}

The result of the vitamins analysis of the stem bark of Napoleonavogelii is shown in table 3.

\section{TABLE 3: The Result of the Vitamins Analysis of the Stem Bark of Napoleonavogelii}

\begin{tabular}{|l|l|}
\hline VITAMINS & QUANTITY PRESENT $(\mathrm{Mg} / \mathrm{g})$ \\
\hline Vitamin A & $1.20 \pm 0.03$ \\
\hline Vitamin E & $1.31 \pm 0.04$ \\
\hline Vitamin C & 2.780 .04 \\
\hline Vitamin B1 & $7.20 \pm 0.05$ \\
\hline Vitamin B2 & $0.90 \pm 0.31$ \\
\hline Vitamin B9 & $4.09 \pm 0.05$ \\
\hline Vitamin B3 & $1.27 \pm 0.25$ \\
\hline Vitamin B6 & $12.50 \pm 0.04$ \\
\hline Vitamin B12 & $8.25 \pm 0.04$ \\
\hline Vitamin B7 & $\mathrm{NIL}$ \\
\hline Vitamin B5 & $\mathrm{NIL}$ \\
\hline
\end{tabular}

Vitamins have diverse biochemical functions. Some, such as vitamin D, have hormone-like functions as regulators of mineral metabolism, or regulators of cell and tissue growth and differentiation. The largest number of vitamins, the B complex vitamins, functions as precursors for enzyme cofactors that help enzymes in their work as catalysts in metabolism. Others function as antioxidants such as vitamin $E$ and vitamin $C$ [29].

The presence of vitamin C (ascorbic acid) in the diet enhances iron absorption, and iron to ascorbic acid ratio provides an index of iron availability in food sample in such a way that the lower ratio, the greater the relative bioavailability of iron [21] Vitamin C prevents many debilitating diseases, increases the body's immunity and is powerful antioxidant [30]. It also helps in recycling other antioxidants and it also aids in the formation of collagen. Collagen, tendons and ligaments depend upon Vitamin C to stay strong and healthy [31].

Vitamin $\mathrm{E}$ provides protection which might include its function as an antioxidant and its roles in anti-inflammatory processes, inhibition of platelet aggregation, and immune enhancement [23]. Vitamin E also may block the formation of nitrosamines, which are carcinogens formed in the stomach from nitrites consumed in the diet [32]lt also may protect against the development of cancers by enhancing immune functions. Some evidence links higher intake of vitamin $E$ to a decreased incidence of prostate and breast cancers [23]. The vitamin A content of the plant is $1.20 \mathrm{mg} / \mathrm{g}$. Vitamin A serves as an antioxidant and is essential for normal growth and for the formation of strong bones and teeth in children, for normal vision and cell structure, for protecting the lining of the respiratory, digestive, and urinary tracts against infection, and for healthy skin [33]. It also functions as a hormone, visual pigment of the vertebrate eye and regulates gene expression in the development of epithelial tissue, including skin [34].

\section{MACRO AND MICRO ELEMENTS ANALYSIS}

The result of the macro and micro elements analysis of the stem bark of Napoleonavogelii is shown in table 4 
TABLE 4: The Result of the Macro and Micro Elements Analysis of the Stem Bark of Napoleonavogelii

\begin{tabular}{|l|l|}
\hline PARAMETERS & NAPOLEONA VOGELI/(mg/kg) \\
\hline Arsenic & BDL \\
\hline Sodium & 1247 \\
\hline Calcium & 2006 \\
\hline Copper & 1.23 \\
\hline Nickel & BDL \\
\hline Phosphorous & 410.22 \\
\hline Iron & 304.66 \\
\hline Potassium & 4996 \\
\hline Manganese & 56.99 \\
\hline Zinc & 2.69 \\
\hline
\end{tabular}

NOTE; BDL - Below Detection Limit $(0.001 \mathrm{mg} / \mathrm{kg})$

Minerals are absolutely necessary for most metabolic processes. They serve as cofactors, help in transmission of nerve impulses and water balance [35]. The level of Calcium is relatively high compared to the level reported for the African yam bean varieties $(70-128 \mathrm{ppm})$ by [36]. Calcium $(2006 \mathrm{mg} / \mathrm{kg})$, is needed for the formation of bones and it supports the synthesis and function of blood cells. Calcium in conjunction with magnesium, chlorine and proteins are involved in the formation of bones [37]. The availability of calcium in the body depends on calcium to phosphorus ratio and presence of antinutritional factors such as oxalate and phytate [38].Sodium and Potassium are necessary to maintain osmotic balance in the body as well as the $\mathrm{pH}$.. Iron is present in considerable amount $(304.66 \mathrm{mg} / \mathrm{kg}$ ) and its necessary in formation of haemoglobin and normal functioning of the central nervous system. Phosphorus, a mineral in bone formation is also present $(410.22 \mathrm{mg} / \mathrm{kg})$. Phosphorus is required for normal function of the body since it is a major structural component of bone and teeth and helps to maintain normal pH [39]. It is crucial for production of ATP and also plays important role in the growth, maintenance and repair of cells and tissues [21]. The other Micro minerals like Manganense, Copper and Zinc are also present and they play important roles in metabolic activities. These elements support human biochemical processes by serving structural and functional roles as electrolytes [34]

\section{ANTIMICROBIAL ANALYSIS}

The result of the antimicrobial activity screening of the stem bark of Napoleonavogelii is shown in table 5

TABLE 5: The Result of the Antimicrobial Activity of the Stem Bark of Napoleonavogelii

\begin{tabular}{|l|l|l|l|l|l|}
\hline & STAPPHYLOCOCCUS & E.COLI & PSEUDOMONAS & STREPTOCOCCUS & CANDIDA \\
\hline BUTANOL & 14.3 & 17.7 & 12.3 & 14.7 & 20.3 \\
& \pm 1.20 & \pm 1.50 & \pm 1.20 & \pm 1.20 & \pm 1.20 \\
\hline ETHANOL & 11.7 & 9.7 & 16.7 & 13.7 & 10.3 \\
& \pm 1.20 & \pm 0.60 & \pm 1.20 & \pm 0.60 & \pm 1.20 \\
\hline CHLOROFORM & 12.3 & 12.3 & 10.7 & 14.7 & 17.3 \\
& \pm 1.20 & \pm 0.60 & \pm 0.60 & \pm 0.60 & \pm 1.20 \\
\hline STD & 24.3 & 24.7 & 12.3 & 18.7 & 12.3 \\
& \pm 1.20 & \pm 1.20 & \pm 1.20 & \pm 0.60 & \pm 1.20 \\
\hline
\end{tabular}

Values show means of triplicate analysis \pm standard deviation.

The antimicrobial activity of the extracts of Napoleonavogelii were studied in different concentrations $(50,100,150,200)$ against four bacterial staphylococcus aureus, streptococcussp, Escherichia coli, pseudomonas aeruginosa and a fungal strain candida albicans. Antibacterial and antifungal potential of extracts were assessed in terms of zone of inhibition of bacterial growth. The results of the antibacterial and antifungal activities are presented in the table. The antibacterial and antifungal activities increased linearly with increase in the concentration of extracts. The result of this study agrees closely with the work of [6] on antimicrobial activity of Napoleonavogelii. In both works, Pseudomonas was significantly inhibited. However, the result could possibly be due to the different extraction solvents used in the different works [15]. 


\section{DIAMETER OF INHIBITION ZONE}

The result of the diameter of inhibition zone of the stem bark of Napoleonavogelii is shown in table 6

TABLE 6:The Result of the Diameter of Inhibition Zone ( $\mathrm{mm}$ ) of the Stem Bark of Napoleonavogelii

\begin{tabular}{|c|c|c|c|c|}
\hline \multirow[t]{2}{*}{ ORGANISM } & \multirow[t]{2}{*}{ CONC. $(\mathrm{mg} / \mathrm{ml})$} & \multicolumn{3}{|c|}{ Diameter Of Inhibition Zone (mm) } \\
\hline & & $\begin{array}{l}\text { BUTANOL } \\
\text { EXTRACT }(\mathrm{mm})\end{array}$ & $\begin{array}{l}\text { ETHANOL } \\
\text { EXTRACT }(\mathrm{mm})\end{array}$ & $\begin{array}{l}\text { CHLOROFORM } \\
\text { EXTRACT }(\mathrm{mm})\end{array}$ \\
\hline $\begin{array}{l}\text { STAPPHYLOCOCCUS } \\
\text { AUREUS }\end{array}$ & $\begin{array}{l}50 \\
100 \\
150 \\
200 \\
\text { Chloramphenicol } \\
(25 \mathrm{mg} / \mathrm{ml})\end{array}$ & $\begin{array}{l}- \\
- \\
10 \\
14 \\
25\end{array}$ & $\begin{array}{l}- \\
- \\
8 \\
12 \\
25\end{array}$ & $\begin{array}{l}- \\
- \\
8 \\
12 \\
23\end{array}$ \\
\hline ESCHERICHIA COLI & $\begin{array}{l}50 \\
100 \\
150 \\
200 \\
\text { Chloramphenicol } \\
(25 \mathrm{mg} / \mathrm{ml})\end{array}$ & $\begin{array}{l}- \\
10 \\
13 \\
18 \\
26\end{array}$ & $\begin{array}{l}- \\
- \\
- \\
10 \\
24\end{array}$ & $\begin{array}{l}- \\
- \\
9 \\
12 \\
24\end{array}$ \\
\hline $\begin{array}{l}\text { PSEUDOMONAS } \\
\text { AERUGINOSA }\end{array}$ & $\begin{array}{l}50 \\
100 \\
150 \\
200 \\
\text { Chloramphenicol } \\
(25 \mathrm{mg} / \mathrm{ml})\end{array}$ & $\begin{array}{l}- \\
- \\
8 \\
12 \\
13\end{array}$ & $\begin{array}{l}- \\
13 \\
14 \\
17 \\
11\end{array}$ & $\begin{array}{l}- \\
- \\
- \\
11 \\
11\end{array}$ \\
\hline STREPTOCOCCUS SP & $\begin{array}{l}50 \\
100 \\
150 \\
200 \\
\text { Chloramphenicol } \\
(25 \mathrm{mg} / \mathrm{ml})\end{array}$ & $\begin{array}{l}- \\
- \\
9 \\
15 \\
18\end{array}$ & $\begin{array}{r}10 \\
14 \\
19\end{array}$ & $\begin{array}{l}- \\
- \\
10 \\
14 \\
19\end{array}$ \\
\hline CANDIDA ALBICANS & $\begin{array}{l}50 \\
100 \\
150 \\
200 \\
\text { Ciprofloxacin } \\
(50 \mathrm{mg} / \mathrm{ml})\end{array}$ & $\begin{array}{l}- \\
9 \\
13 \\
20 \\
33\end{array}$ & $\begin{array}{l}- \\
- \\
- \\
10 \\
31\end{array}$ & $\begin{array}{l}- \\
10 \\
13 \\
17 \\
31\end{array}$ \\
\hline \multirow[t]{2}{*}{ ORGANISM } & \multirow{2}{*}{$\begin{array}{l}\text { CONCENTRATIN }(\mathrm{m} \\
\mathrm{g} / \mathrm{ml})\end{array}$} & \multicolumn{3}{|c|}{ Diameter Of Inhibition Zone (\%) } \\
\hline & & $\begin{array}{l}\text { BUTANOL EXTRAC } \\
(\%)\end{array}$ & \begin{tabular}{l|l} 
T & ETHANOL \\
EXTRACT \\
$(\%)$
\end{tabular} & $\begin{array}{l}\text { CHLOROFORM } \\
\text { EXTRACT } \\
(\%)\end{array}$ \\
\hline
\end{tabular}




\begin{tabular}{|c|c|c|c|c|}
\hline $\begin{array}{l}\text { STAPPHYLOCOCCUS } \\
\text { AUREUS }\end{array}$ & $\begin{array}{l}50 \\
100 \\
150 \\
200\end{array}$ & $\begin{array}{l}- \\
- \\
40 \\
56\end{array}$ & $\begin{array}{l}- \\
- \\
32 \\
48\end{array}$ & \begin{tabular}{|l|}
- \\
- \\
32 \\
48
\end{tabular} \\
\hline ESCHERICHIA COLI & $\begin{array}{l}50 \\
100 \\
150 \\
200\end{array}$ & $\begin{array}{l}- \\
40 \\
52 \\
72\end{array}$ & $\begin{array}{l}- \\
- \\
- \\
40\end{array}$ & \begin{tabular}{|l|}
- \\
- \\
36 \\
48
\end{tabular} \\
\hline $\begin{array}{l}\text { PSEUDOMONAS } \\
\text { AERUGINOSA }\end{array}$ & $\begin{array}{l}50 \\
100 \\
150 \\
200\end{array}$ & $\begin{array}{l}- \\
- \\
32 \\
48\end{array}$ & $\begin{array}{l}- \\
52 \\
56 \\
68\end{array}$ & \begin{tabular}{|l}
- \\
- \\
- \\
44
\end{tabular} \\
\hline STREPTOCOCCUS SP & $\begin{array}{l}50 \\
100 \\
150 \\
200\end{array}$ & $\begin{array}{l}- \\
- \\
36 \\
60\end{array}$ & $\begin{array}{l}- \\
- \\
40 \\
56\end{array}$ & \begin{tabular}{|l}
- \\
- \\
40 \\
56
\end{tabular} \\
\hline CANDIDA ALBICANS & $\begin{array}{l}50 \\
100 \\
150 \\
200\end{array}$ & $\begin{array}{l}- \\
18 \\
26 \\
40\end{array}$ & $\begin{array}{l}- \\
- \\
- \\
20\end{array}$ & \begin{tabular}{|l}
- \\
20 \\
26 \\
34
\end{tabular} \\
\hline
\end{tabular}

The antimicrobial activity of the extracts were studied in different concentration $(50,100,150,200)$ against four pathogenic bacterial strains, two Gram-positive (Staphylococcus aureus, Streptococcus sp.) and two Gram-negative (Escherichia coli, Pseudomonas aeruginosa ), and a fungus strain Candida albicans). Antibacterial and antifungal potential of extracts were assessed in terms of zone of inhibition of bacterial growth. The growth inhibition zone measured ranged from 7 to $19 \mathrm{~mm}$ for all the sensitive bacteria, and ranged from 9 to $21 \mathrm{~mm}$ for fungal strain. In this study, the results showed that the three extracts of Napoleonavogelii possess antimicrobial activities against the tested organisms at different concentrations. With the butanol extract, the highest antimicrobial activity of $18 \mathrm{~mm}$ in E.coli and least activity of $8 \mathrm{~mm}$ in streptococcus were recorded. With the ethanol extract, the highest antimicrobial activity of $17 \mathrm{~mm}$ in pseudomonas and least activity of $8 \mathrm{~mm}$ in staphylococcuswas recorded. With the chloroform extract, the highest antimicrobial activity of $15 \mathrm{~mm}$ in streptococcus and least activity of $8 \mathrm{~mm}$ in staphylococcus were recorded. Butanol extract demonstrated a better antifugal activity than the other extracts. The results of the present investigation clearly indicates that the antibacterial and antifungal activity vary with the different solvent used in extraction. Thus the study ascertains the value of solvents used for extraction which could be of considerable interest to the development of new drugs. 


\subsubsection{MINIMUM INHIBITION CONCENTRATION (MIC)}

The minimum inhibition concentration of the stem bark of Napoleonavogelii is shown in table 7

TABLE 7: The Minimum Inhibition Concentration (MIC) in $\mathrm{mg} / \mathrm{ml}$ of the Stem Bark of Napoleonavogelii

\begin{tabular}{|l|l|l|l|l|l|}
\hline EXTRACTS & STAPHYLOCOCCUS & E.COLI & PSEUDOMONAS & STREPTOCOCCUS & CANDIDA \\
\hline BUTANOL & 150 & 100 & 150 & 150 & 100 \\
\hline ETHANOL & 150 & 200 & 100 & 150 & 200 \\
\hline CHLOROFORM & 150 & 150 & 200 & 150 & 100 \\
\hline
\end{tabular}

The minimum inhibition concentration (MIC) presented in the table above shows that the values of the different extracts ranged between $100 \mathrm{mg} / \mathrm{ml}-200 \mathrm{mg} / \mathrm{ml}$. With the butanol extract, the MIC ranged from $100 \mathrm{mg} / \mathrm{ml}$ on E.coli and Candida to $150 \mathrm{mg} / \mathrm{ml}$ on staphylococcus, pseudomonas and streptococcus. Ethanol extract however had MIC range between $100 \mathrm{mg} / \mathrm{ml}$ for pseudomonas, $150 \mathrm{mg} / \mathrm{ml}$ for staphylococcus aureus and streptococcus and then $200 \mathrm{mg} / \mathrm{ml}$ for E.coli and Candida. Chloroform extract had MIC range between $100 \mathrm{mg} / \mathrm{ml}$ for Candida, $150 \mathrm{mg} / \mathrm{ml}$ for staphylococcus, E.coli and streptococcus, and $200 \mathrm{mg} / \mathrm{ml}$ for pseudomonas.

\section{CONCLUSION}

The result of this study revealed the presence of most of the phytochemicals with various biological activities. This might be responsible for the observed antimicrobial activities against test organisms. The important minerals found in the stem bark may also be major contributors to the medicinal use of the plant. This data indicates that Napoleonavogelii stem bark contains potent bioactive compounds and justifies the claimed use of the stem bark in the traditional system of medicine to treat infectious diseases such as skin diseases caused by microbes

\section{ACKNOWLEDGEMENT}

The authors aregrateful to the National Root Crop Resarch Institute Umudike for assistingheir equipment for the anti microbial analysis and the Golden Year Ltd Port Harcourt for the use of their AAS equipment.

\section{REFERENCES}

1 Belonwu,D.C.; Ibegbulem,C.C.; Nwokeocha, M.N. and Chikezie,P.C. (2014) "Some Phytochemicals and Hydrophilic Vitamins of Anacardium Occidental". Research Journal of Phytochemistry, 8:78-91

2 Tiwari, P.; Kumar, B.; Kuar, M.; kuar, G. and kuar, H. (2011) “phytochemicals” Int. Pharm. Sci. 1: 98-106

3 Lalitha,T.P. and Tayanthi P.(2012) “Phytochemicals” Asian J. Plant Sci. Res. 1(2): 115-122.

4 Paret, S.K.; Patra,K.C.; Mazumder, P.M. and Sasmal D.(2011) "Establishing the Principle of Herbal Therapy for Antiurolithiatic activity". A Review J. of Pharmacol, Toxicol6:321-332

5 Akah, P.A.; Nnaeto, O.; Nwoni, S.; Ezike, A.C. (2007) " Medicinal Plants Used in the tradition treatment of Peptic Ulcer Diseases". Res J. Pharm, 1:67-74

6 Christian, A; Abraham, Y.M; Kwame, S; Gustav, K; (2006), "Antimicrobial activity of HymenostegiaafzeliiandNapoleaneaVogelii” BoletínLatinoamericanoy del Caribe de PlantasMedicinalesyAromáticas, $5(1): 2-61$

7 Enye, J.C.; Chineka, H.N.; Onubeze,, D.P.M.; Nweke I. (2013) "Wound Healing Effect of Methanol Leaf Extract of Napoleonavogelii (Lecythidaceae)".Journal of Dental and Medical Sciences, 8 (6):31-35

8 Igiji,O.J.; Nwabue,F.I. and Omaka O.N.(2011) "Physicochemical Studies of Extract from Napoleonavogelii grown in Ebonyi State as a Source of New Acid-Base Indicator". ResearchJournal in Engineering and Applied Science, 1(2) 96101

9 AOAC (Association of official Analytical chemist); (2012), Official methods of analysis . 19th edition Washingtion DC

10 Sofowara (1993) "Medicinal Plants and Traditional Medicine in Africa 2ndEdn spectrum books L.T.D, Ibadan,Nigeria. 289.

11 Trease G.E. and Evans W.C. (2009) pharmacognosy16thEdnSauders Elsevier limited. New York 104-262.

12 AOAC (Association of official Analytical chemist); (1990), Official methods of analysis . 15th edition Washingtion DC

13 Sharpless, K.E; Margolis, S; Thomas J.B; (2000), "Determination of vitamins in food matrix standard reference materials". Journal of Chromatography 9:881(1-2):171-81

14 Santos, J; Mendiola J.A; Oliveira M.B; Ibanez, E; Herrero, M; (2012), "Sequential determination of fat and water soluble vitamins in green leafy vegetables during storage". Journal of Chromatography 126:179-188 
15 Njoku O.U.;J.A.E. Boniface ;N.C.Obita ;Odimegwu D.C. and H.I. Ogbu (2010) "Nutritional Potential of Benisied Oil”. Int. j. appl. Res. Nat. prd., 2:11-19.

16 Akpona,H.A.;Akpona, J.D.T.;Awokou, S.K.; Yemoa, A. and Dossasa I.O.(2009) "Inventory Folk Classification and Pharmacological Properties of Plant Species used as Chewing Stick in Benin Republic". J. of Medicinal Plants Research, 3: 382-389

17 Anderson KJ, Teuber SS, Gobeille A, Cremin P, Waterhouse AL, Steinberg FM (2001)."Walnut polyphenolics inhibit in vitro human plasma and LDL oxidation". J. Nutri. 131: 2837-2842.

18 Hameed ESSA (2009)."Total phenolic contents and free radical scavenging activity of certain Egyptian Ficus species leaf samples". Food Chem. 114: 127

19 Galeotti F, Barile E, Curir P, Dolci M, Lanzotti V (2008).“Flavonoids from carnation ( Dianthuscaryophyllus ) and their antifungal activity". Phytochem. Lett. 1: 44-48.

20 Mattila P, Hellstrom J (2007).“Phenolic acids in potatoes, vegetables, and some of their products”.J. Food Composition Analysis, 20: 152- 160.

21Omonkhelin, Josephine;Owolabi, Silvanus O.;Inninh,ogochukwu;Ngozi,Anaka and Osareti, Abiemwenselyamu (2014) “ Antidiabetic and hypolipidemic effects of methanol leaf extract of Napoleonavogelii Hook and Planch on Alloxan Induced Diabetic Mellitus in Rats.Tropical".Journal of Pharmaceutical Research 3(11): 1903-1909

22lgidi, O. J; Edene, C; (2014), "Proximate and phytochemical compositions of Napoleonavogeliihook fruit" The International Journal of Engineering and Science, 3(6):46-51

23 George O. (2009). The role of Vitamin E (The Vitamin and Nutrition centre (2009)..Bulletin of the Science Association off Nigeria, 26: 362-327.

24 Shi, J; Arunasalam, K; Yeung, O; Kakuda, Y; Mittal, G; and Jiang Y. (2004): "Saponins from Edible Legumes; Chemistry Processing and Health Benefits", Journal of Med. Food, 7(1): pp67 - 78.

25 Qin, Y; Wu, X; Haung, W; and Gong, G. (2009)."Acute Toxicity of Substances and Chronic Toxicity of Steroidal Saponin from DioscoraZingiberesis in Rodent”.Journal of Ethnophamacology: 126(3): 543-650.

26 Mgbagwu, F. N; Chuba, C; Unamba, C. I. N; and Nwosu, I. C. (2010): Proximate Analysis and Mineral Composition of Seeds of Treculia Africana and ArtocarpulusAtiti (Mora Leae); InternationalScience Research Journal, 2: pp 121 - 123.

27 Kalu, F. N.; Ogugua, V. N. I; Ujowumdi, C. O; and Chinekeokwu, C. R. K. (2011): Chemical Composition and Aluta Toxicity Studies on the Aqueous Extract of CombretumDolichopentalum Leaf in Swiss Albino Mice. J. Chem Sci. Research. 1:18

28 European Food Safety Authority. (2011): Scientific Opinion on the Risks for Public Health Related to the Presence of Opium Alkaloids in Poppy Seeds. EFSA Journal. 9 (11): 2405.

29 Bender, David A. (2003) nutritional biochemistry of the vitamin.cambridge, Uk Cambridge University press

30 Bjelakoni, G., Nikolora, D., Gluad, L.L., Simonette, R.G. and Gluad, C. (2007)."Mortality in randomized trials of antioxidants supplements for primary and secondary prevention. System review and Metal Analysis".Journal of American Malnutrition Association, 297(8): 842- 857.

31 John, A. (2009). Health benefits of Vitamin C, Importance of vitamin C (www.articlesbase.com) 1st July

32 Hassan, S.W., Umar, R.A., Ladan M.J., Nyemike, P., Wasagu R.S.U., Lawal, M. and Ebbo .A. A. (2007).Nutritive value, phytochemical and Antifungal Properties of Pergulariatomentosa L. (Asclepiadaceae).International Journal of Pharmacology, 3(4): 334-340.

33 Damon M. (2009). The importance of Vitamin A in your diet. Association content, Health and wellness (associated content. com.

34 Nelson, D.C. and Cox, M.M. (1999).Lehninger Principle of Biochemistry, 4th Ed, W. H. Freeman and Company New York pp 361-362.

35Brown, A.C. (2007). Chemistry of Food Composition: Understanding Food: Properties and preparation 3rd Edn., Wadsworth Publishing Co., United States, pp. 46-49.

36Fagbemi, T.N., 2004. Processing effect on the chemical composition and functional properties of three tropical seeds: Breadnut (Antrocarpusattilis), Cashewnut (Anacardiumcocidentails) and Fluted pumkin(Te1faria occidentails). Ph.D. Thesis, Chemistry Department Federal University of Technology, Akure, Ondo State, Nigeria.Guisseppe, R. and T.M. Baratta, 2000. Antioxidant activity of selected essential oil components in two lipid model systems. Afr. J. Biotechnol., 69(2): 167-174.

37Abullude, F.O. Lawal, I.O. and Onibon, V.O. (2007)."Nutritional and anti-nutritional composition of someNutritive values, Mineral and Antioxidant properties of Pistiastratiotes Nigerian Fruits". Journal of Food Technology, 5: 120-122.

38 Bentliff, G. and Kosler, J. (2006). Food science, nutrition and health.7th edition.Edward Arnold publisher Ltd. Pp 187189. 
39 Knochel, J.P. (2006).Phosphorus. In: Shils, M.E., Shike, M, Ross, A.C., Caballero, B., Cousins, R.J, eds. Modern Nutrition in health and diseases. 10th ed. Baltimore: Lippincott williams and Wilkins; pp: 211-222. 